\title{
SEJARAH INDONESIA DALAM KONTEKS POLITIK GLOBAL DAN REGIONAL
}

\author{
Linda Sunarti \\ Departemen Sejarah, Universitas Indonesia
}

\begin{abstract}
Abstrak. Sejarah Indonesia akan terlihat sangat menarik untuk dipelajari ketika dianalisis secara regional dan global. Salah satu cara yang dapat dipakai adalah pendekatan komparatif. Terdapat beberapa aspek dalam melihat sejarah komparatif. Unsur waktu, ruang, dan topik harus seimbang. Oleh karena itu, para sejarawan harus melihat aspek sejarah, budaya, geografi, dan geo-politik dalam membandingkan perkembangan kebijakan luar negeri Indonesia dan Malaysia pasca kemerdekaan. Selain itu, pengalaman kolonialisme yang berbeda perlu diwaspadai. Hal ini berdampak pada pembentukan karakter dan persepsi yang berbeda terhadap masalah keamanan nasional masing-masing negara. Posisi geografis yang strategis menjadikan Asia Tenggara sebagai arena perebutan pengaruh ideologi antara blok Barat dan blok Timur pada masa perang dingin. Dalam menghadapi situasi perang dingin yang terjadi, Indonesia dan Malaysia, berlatar belakang kepentingan nasional yang berbeda, berada dalam dua kubu yang berseberangan. Tulisan ini berupaya untuk memberikan model bagaimana menuliskan sejarah dengan perspektif global.
\end{abstract}

Kata-kata kunci: sejarah Indonesia, sejarah global, sejarah regional

\begin{abstract}
Indonesian history could be interesting to elaborate further when it is analyzed regionally and globally. An attempt to be used is a comparative study. There are various aspects in looking at comparative history. Time, place, and topic should be equal. Therefore, historians should look at the historical, cultural, geographical, and geo-political aspects in comparing the development of Indonesian and Malaysian foreign policies. In addition, the different colonial experience should be realized. This will be affected on the various character building and perception on the each national security. Southeast Asia becomes an arena to be competed between Western and Eastern ideologies. In the wave of the cold war, Indonesia and Malaysia have different interest and different position. This article tries to give a model how to write history based on global perspective
\end{abstract}

Keywords: Indonesian history, global history, regional history

Indonesia adalah negara terbesar di kawasan Asia tenggara baik dari segi luas wilayah maupun jumlah penduduknya. Dalam perjalanan sejarahnya Indonesia bisa dikatakan memainkan peranan yang sangat penting. Di Indonesia lah kerajaan-kerajaan besar yang memiliki pengaruh luas di kawasan Asia Tenggara pernah berdiri. Contoh nya adalah Kerajaan Sriwijaya dan Majapahit, Samudra Pasai, Banten, Aceh dll. Dalam konteks sejarah Indonesia modern, Indonesia adalah salah satu negara yang memprakarsai berdirinya ASEAN dan berkontribusi penting dalam menjaga stabilitas kawasan selama hampir lebih dari 3 dekade. Pembentukan komunitas masyarakat ASEAN tidak terlepas dari kontribusi besar Indonesia. Dengan modal sebagai negara terbesar di kawasan Asia Tenggara ditinjau dari luas wilayah dan penduduk, sumber daya alam, posisi geopolitik, serta budaya dan tradisi itulah yang membuat Indonesia percaya diri sebagai negara terpenting di kawasan Asia Tenggara.

Melihat kedudukan dan peranan Indonesia yang begitu penting dalam konteks perjalanan Sejarah Kawasan atau "region" Asia Tenggara, maka tidak berlebihan jika dalam penulisan sejarah Indonesia, para sejarawan diharapkan bisa menggunakan pendekatan regional/ perfektif regional dalam menganalisis peristiwa-peristiwa sejarah yang terjadi di Indonesia. Saat ini, sangat sedikit sejarawan Indonesia yang menulis sejarah regional maupun global, minimal melakukan komparasi atau koneksi antara Indonesia dengan negara-negara Asia Tenggara. Menurut Anthony Reid pada sebuah edisi khusus majalah Tempo menyatakan bahwa kajian-kajian sarjana Indone- 
sia terlalu fokus dengan Indonesia dan melupakan aspek-aspek global dan regional.

Sejarah adalah sebuah peristiwa yang mempunyai lingkup dan jangkauan yang luas. Setiap masa mempunyai sebuah peristiwa universal yang pertama-tama harus kita ketahui bila kita ingin menulis sejarah sebuah tempat. Misalnya, Zaman Liberal (1870-1900) di Hindia Belanda tidak bisa dilepaskan dengan perubahan besar di lingkup global yaitu Revolusi Industri dan kuatnya pemikiran liberalisme ekonomi di Eropa. Sejarah Indonesia pada periode 19451965 tidak bisa dilepaskan dari konteks global dan regional yang mewarnai masa itu. Situasi Perang Dingin begitu kuat mempengaruhi sejarah kawasan Asia Tenggara dan Indonesia. Peristiwa-peristiwa politik yang terjadi di Indonesia seperti, pemberontakan PRRI -Permesta, Konferensi Asia Afrika, Irian Barat, Deklarasi Juanda dan Konfrontasi (yang akan menjadi pokok bahasan saya dalam tulisan ini) bisa dipahami dengan baik jika kita mengkaitan peristiwa-peristiwa tersebut dengan menggunakan persfektif regional dan global.

Sebuah warna universal dalam sejarah jika dibaca dan dipahami dengan baik akan memunculkan fenomena lain, apa yang disebut dengan "interkoneksi". Karena bersifat global maka tidak mungkin tidak ada keterkaitan antara satu peristiwa dengan peristiwa lain, biasanya ada simpul-simpul yang berhubungan yang mewarnai peristiwa tersebut. Munculnya gerakan kebangsaan dan perlawanan terhadap kolonialisme Eropa di Asia Tenggara pada awal abad ke20 tidak bisa dilepaskan dari interkoneksi global dan regional yang terjadi pada masa itu. Gerakan nasionalis dan anti kolonial di awal abad 20 memiliki sebuah jalinan, di mana para tokohtokoh nasionalis Asia bertukar ide dalam organisasi Liga Anti Penindasan pada Konferensi Brussel 1927. Dari interkoneksi itu bisa dikatakan bahwa KAA di Bandung tahun 1955 adalah sebuah peristiwa global yang tidak lahir secara tiba-tiba karena perang dingin saja, namun sebenarnya akar-akarnya telah terbentuk dari interkoneksi antara pemimpin-pemimpin Asia dan Afrika dalam jaringan gerakan anti im- perialisme dan kolonialisme sejak awal abad ke20.

Satu hal yang paling penting dari dua hal diatas, adalah dengan melihat sejarah Indonesia melalui persfektif global/regional akan mendorong kita melakukan studi komparasi atau perbandingan . Studi komparasi sangat penting untuk melihat sejauh manakah perbedaan atau kesamaan mempengaruhi kehidupan sosial, ekonomi , budaya dan politik masyarakat di suatu tempat atau pada era tertentu. Tidak ada peristiwa tanpa sebab akibat. Di sinilah analisis sejarah akan terus selalu relevan dan sebuah analisis yang baik bila dilakukan dengan membandingkan suatu hal yang ingin kita analisis dengan wilayah yang mempunyai corak yang hampir sama. Studi komparasi akan memberikan hasil yang bisa mengungkapkan mengapa misalnya masyarakat A seperti itu dan masyarakat B seperti itu, apa yang menyebabkan perbedaan dan apa yang bisa diambil dari perbandingkan itu.

Dalam tulisan ini saya akan mencoba memberikan contoh bagaimana menganalisis sebuah peristiwa sejarah yang terjadi di Indonesia yaitu konfrontasi antara Indonesia dan Malaysia pada tahun 1963-1966 dengan menggunakan pendekatan global/regional, serta membandingkan apa yang terjadi di Indonesia dan Malaysia pada era yang sama, apa yang menyebabkan perbedaan sikap kedua negara dalam memandang "Barat"atau negara-negara Eropa yang pada akhirnya memicu konflik kedua negara.

Dalam rangka memahami keterkaitan antara struktur politik global, regional dan domestik (Indonesia-Malaysia), penulis terlebih dahulu menjelaskan kondisi geografis dan geo politik Asia Tenggara, yang secara tidak langsung telah membentuk karakter sosial, budaya dan politik kedua negara (Indonesia-Malaysia). Dalam tulisan ini juga akan diuraikan situasi Indonesia politik dan budaya di kedua negara yang terkait konteks kedudukan geografis kedua negara di Asia Tenggara. Selain itu dalam tulisan ini, penulis akan menjelaskan munculnya Perang Dingin dan dampaknya terhadap situasi politik di Asia Tenggara. 


\section{GAMBARAN UMUM ASIA TENGGARA}

Asia Tenggara (Amerika: Southeast, Inggris: South East) merupakan istilah umum yang dipakai pada masa Perang Dunia kedua. Untuk menggambarkan wilayah daratan Asia Bagian Timur yang terdiri dari Jazirah Indocina dan banyak kepulauan yang meliputi IndonesiaFilipina (Hall, 1988:3). Dengan demikian Asia Tenggara merupakan daratan dan kepulauan di sudut Tenggara benua Eurasia. Meskipun Asia Tenggara tidak merupakan entitas politik dan kebudayaan, negara-negaranya menunjukan persamaan dalam struktur sosial dan ekonomi. Dalam tahap-tahap evolusi, sejarah wilayah ini menunjukan adanya variasi-variasi dasar kebudayaan.

Istilah Asia Tenggara ini sebenarnya istilah kontemporer yang digunakan oleh Angkatan Perang Inggris-Amerika pada 1941, yang berkedudukan di Ceylon dalam melawan tentara Jepang pada masa Perang Dunia II. Orang Amerika Serikat menulis istilah ini dengan Southeast, sedangkan orang Inggris menulisnya dengan South East. Tetapi sebenarnya istilah ini sama saja, karena mengandung pengertian suatu wilayah entitas politik daratan Burma, Thailand, Vietnam, Laos, kamboja, wilayah kepulauan Indonesia, Philipina, Semenanjung Malaya (Malaysia dan Singapura), dan daerah protektorat Inggris (Brunai Darussalam).

Posisi Asia Tenggara terbentang di persimpangan dua jalur laut terbesar di dunia. Pertama adalah jalur Timur-Barat, yaitu jalur yang menghubungkan Samudera Hindia dengan Samudera Pasifik. Kedua adalah jalur UtaraSelatan, yang menghubungkan kawasan Asia Timur dengan Australia dan Selandia Baru serta pulau disekitarnya (Sokolosky, Rabasa, Nieu, 2000:10).

Tiga pintu masuk kawasan Asia Tenggara Selat Malaka, Selat Sunda dan Selat Lombok merupakan titik penting dalam sistem perdagangan dunia. Selat Malaka sendiri merupakan selat yang menghubungkan Samudera Hindia dengan samudera Pasifik, sekaligus sebagai jalur terpendek yang terletak diantara India, Cina dan Indonesia, oleh karena itu selat ini dianggap sebagai "chokepoints" Asia.

Letak Asia Tenggara yang strategis berdasarkan jalur ini, tentu saja menempatkan Asia Tenggara sebagai kawasan yang sangat penting baik ekonomi maupun keamanan. Didasarkan pada letak geografisnya yang berada dipersimpangan jalur perdagangan dunia baik di masa kuno sampai modern, Asia Tenggara banyak menerima pengaruh dari luar.

Sejarah Asia Tenggara banyak ditentukan oleh aspek dari luar yaitu: perdagangan dengan bangsa asing; India, Cina, Arab, dan kemudian Eropa. Sistem kenegaraan dan politik pra modern di Asia Tenggara banyak mendapatkan pengaruh dari kebudayaan India, seperti konsep dewa raja dan mandala. Faktor penting lainnya dari pengaruh budaya India adalah masuknya agama Hindu-Budha, yang saat ini banyak dianut oleh masyarakat daratan Asia Tenggara, seperti Thailand, Myanmar, Vietnam, Laos dan Kamboja.

Sedangkan Pengaruh Cina, secara budaya dan sistem politik terdapat di wilayah yang dikenal sebagai Indo China yaitu Vietnam, Laos dan Kamboja. Terutama di Vietnam sistem politik nya lebih banyak mengadaptasi sitem politik China seperti konsep Mandarin.

Setelah masuknya pengaruh HinduBudha yang datang pada awal abad pertama Masehi, kedatangan Islam pada tahun 1200 an Masehi, juga memiliki pengaruh yang sangat besar bagi perkembangan sejarah kawasan ini. Proses Islamisasi yang dimulai sejak abad ke-13 Masehi telah membuat Islam menjadi salah satu unsur penting dalam perkembangan sejarah Asia Tenggara selanjutnya. Saat ini, Islam menjadi agama mayoritas yang di anut oleh sebagian besar penduduk di Kepulauan Indonesia, Malaysia, Filipina Selatan dan Thailand Selatan. Bahkan di Malaysia Islam dijadikan sebagai agama resmi negara, sedangkan Indonesia meskipun Islam di anut oleh hampir 80\% penduduknya Islam tidak dijadikan agama resmi negara. Saat ini Indonesia adalah penduduk 
beragama Islam terbesar di dunia dan juga di Asia Tenggara.

Kedatangan bangsa Eropa yang mulai terjadi sejak awal abad ke-16, memiliki dampak yang sangat penting bagi perkembangan sejarah Asia Tenggara modern. Bisa dikatakan kedatangan bangsa Eropa bersamaan dengan ekspansi kolonialisme merupakan penyebab terbentuknya negara-negara modern Asia Tenggara saat ini.

Penguasaan kolonial memberikan dampak yang nyata terhadap wilayah Asia Tenggara. Kekuatan-kekuatan kolonial memang memperoleh keuntungan yang besar dari sumber daya alam dan pasar Asia Tenggara yang besar. Akan tetapi, mereka juga mengembangkan wilayah ini dengan tingkat perkembangan yang berbeda-beda. Perdagangan, hasil pertanian, pertambangan dan ekonomi berbasis ekspor berkembang dengan cepat pada periode ini. Peningkatan permintaan tenaga kerja menghasilkan migrasi besar-besaran terutama dari India dan Cina. Sehingga terjadilah perubahan demografis yang cukup besar. Munculnya lembaga-lembaga bangsa modern seperti birokrasi pemerintahan, media cetak dan juga pendidikan modern yang turut menaburkan benih-benih kebangkitan gerakan-gerakan nasionalisme di wilayah-wilayah jajahan tersebut.

Kolonialisme Perancis di Indocina, telah membentuk negara Vietnam, Kamboja dan Laos. Begitu pula dengan kolonialisme Inggris yang kemudian membentuk negara Myanmar, Malaysia, Singapura dan Brunai Darussalam. Kolonialisme Belanda di kepulauan Nusantara membentuk negara terbesar di Asia Tenggara saat ini, Indonesia, sedangkan Filipina merupakan bentukan dari kolonialisme Spanyol dan Amerika Serikat.

Kolonialisme Eropa di Asia Tenggara, tidak saja memberikan dampak pada pembentukan negara modern namun juga memberikan dampak besar pada berbagai aspek lainnya yaitu ekonomi, sosial dan juga sistem politik. Kolonialisme Eropa telah mengubah sistem ekonomi Asia Tenggara yang sebelumnya hanya berfokus dan sistem ekonomi swara diri "self sufficient" menjadi sistem ekonomi yang berorientasi ekspor yang bersifat kapitalis.

Dampak dari pengenalan sistem ekonomi kapitalis di awal abad ke-20, Asia Tenggara mulai mengenal tanaman-tanaman ekspor seperti kopi, teh, gula, karet, kelapa sawit, dan lain-lain. Penetrasi ekonomi kapitalis ini selanjutnya membawa dampak perubahan yang yang sangat signifikan terhadap perubahan komposisi penduduk di beberapa wilayah Asia Tenggara, seperti Malaysia dan Myanmar. Kebutuhan akan tenaga kerja yang besar yang tidak bisa dipenuhi oleh sumber daya lokal, menyebabkan pemerintah kolonial membawa masuk para burah dari luar kawasan Asia Tenggara seperti dari Cina dan India. Kedatangan para buruh ini selanjutnya berdampak pada perubahan komposisi penduduk di beberapa negara Asia Tenggara. Sebagai contoh Malaysia, sebelum abad ke 18 mayoritas penduduk Tanah Melayu adalah orang Melayu, namun sejak awal abad ke-20, komposisi tersebut berubah dengan masuknya buruh dari Cina dan India. Saat ini etnis Cina dan India menjadi etnis terbesar kedua dan ketiga di Malaysia.

Selain perubahan komposisi penduduk, kolonialisme Eropa juga telah memperkenalkan sistem birokrasi modern. Pembentukan birokrasi modern merupakan dampak dari kebutuhan pemerintah kolonial untuk memfasilitasi peningkatan perkembangan ekonomi kapitalisnya. Selanjutnya, sistem birokrasi modern ala Eropa inilah yang diwarisi oleh negara-negara di Asia Tenggara pasca kemerdekaannya. Seperti, negara-negara di Indocina mewarisi sitem politik dan birokrasi yang diwariskan oleh Perancis, begitu pula Malaysia sistem birokrasinya merupakan warisan kolonialisme Inggris, Indonesia dari Hindia Belanda, Filipina dari Amerika Serikat.

Selain dampak-dampak di atas, kolonialisme Eropa juga berdampak pada keberagaman sistem politik dan ekonomi yang dianut oleh negara-negara di Asia Tenggara. Pengalaman kolonialisme yang berbeda 
membuat bangsa-bangsa di Asia Tenggara memiliki persepsi yang berbeda terkait hubungan mereka dengan bangsa-bangsa di luar Asia Tenggara dan bahaya terhadap ancaman nasionalnya.

\section{INDONESIA DAN MALAYSIA DALAM KONTEKS REGIONAL}

Dari segi geografi, Indonesia adalah bagian dari kawasan Asia Tenggara. Indonesia terletak disepanjang garis Khatulistiwa antara bagian ujung daratan Asia Tenggara dengan Australia. Oleh karena itu kedudukan Indonesia terlihat seperti sebuah jembatan antara Asia dan Australia. Indonesia terbujur kira-kira $5543 \mathrm{~km}$ dari arah timur ke barat, dan $1227 \mathrm{~km}$ dari Utara dan Selatan. Sebagian besar Kepulauan Indonesia terletak di bagian selatan garis Khatulistiwa. Indonesia mempunyai luas wilayah kira-kira 1,9 juta $\mathrm{km}$ persegi yang meliputi 13.667 buah pulau (Hardjono, 1971:3-4). Luas wilayah Indonesia 12 kali lipat dibandingkan luas Tanah Melayu. Di antara pulau pulau terpenting Indonesia, Kalimantan, Sumatera, Jawa, Sulawesi, dan Irian Barat. Tanah Melayu terletak di tengah-tengah Indonesia.

Posisi geografis Indonesia dan Tanah Melayu memiliki arti penting dalam hubungan awal kedua negara tersebut. Kedua negara terletak di sepanjang jalur perdagangan antara Cina dan India sejak jaman kuno. Posisi ini telah menyebabkan wilayah kedua negara mendapatkan pengaruh dari India dan Cina. Pengaruh dua peradaban tersebut dapat dilihat dalam kebudayaan, sosial dan agama masyarakat setempat. Pengaruh India terdapat dalam seni, arsitektur, kesusasteraan dan adat istiadat masyarakat senelum kedatangan Islam pada abad ke-13. Agama Hindu-Budha merupakan agama yang dianut oleh mayoritas masyarakat di Kepulauan Indonesia dan Semenanjung Melayu. Hal ini dibuktikan dengan keberadaan candi-candi-candi di Sumatera, Jawa dan Semenanjung Melayu .Pengaruh Cina lebih pada aspek politik. Kerajaan-kerajaan di kawasan dunia Melayu seperti
Sriwijaya, Majapahit dan Malaka pernah mengadakan hubungan diplomatik dengan Cina.

Kedudukan geografis Semananjung Tanah Melayu yang terletak berhampiran dengan kepulauan Indonesia, khususnya dengan Pulau Sumatera dan Pulau Jawa, telah menyebabkan penduduk di Semenanjung lebih terpengaruh oleh kebudayaan dari wilayah kepulauan Indonesia, dibandingkan dengan kebudayaan Asia Tenggara daratan (Thailand dan Indochina) (SarDesai, 1980:5).

Selat Malaka merupakan selat yang terletak di antara pantai Timur Sumatera dengan pantai barat Semenanjung Tanah Melayu merupakan jalur laut yang penting bagi hubungan perdagangan Timur-Barat atau perdagangan India-Ciba. Kegiatan perdagangan di selat ini telah memajukan kerajaan-kerajaan yang berada di sepanjang selat seperti, Palembang, Kedah, Melayu (Jambi) dan Malaka. Kepentingan perdagangan telah menyebabkan munculnya kerajaan-kerajaan besar yang bercorak Maritim seperti Srwiwija dan Malaka. Jadi kedudukan geografi Indonesia dan Tanah Melayu telah memainkan peranan yang penting dalam hubungan antara kedua wilayah tersebut, terutama dari segi perkembangan perdagangan dan perkembangan kebudayaan.

Terdapat beberapa persamaan penting yang menonjol dalam hubungan awal kedua negara. Persamaan itu bisa dikihat dari aspek rumpun bangsa, bahasa, agama, kebudayaan dan pekerjaan. Dari segi rumpun bangsa, penduduk pribumi Indonesia dan Malaysia dikenal sebagai orang Indonesia (Indonesian) atau orang Melayu (Malaysian) (Tate, 1977:72 dan Harrison, 1966:xi). Penduduk pribumi Malaysia dan Indonesia umumnya berasal daripada rumpun bangsa yang sama, yaitu rumpun Mongoloid yang berasal dari bagian selatan Cina (Yunan). Mereka datang ke Asia Tenggara pada sekitar 2500 SM. Menurut teori antropolog Belanda P Sarasin, orang Melayu datang ke Asia Tenggara dalam dua gelombang. Gelombang pertama merupakan kelompok yang dikenal sebagai melayu Proto dan kelompok kedua dikenal sebagai Melayu Deutro. Perbedaan masa kedatangan kelompok 
Melayu proto dan Melayu Deutro memiliki selesih waktu 2000 tahun (Vlekke, 1967:9-10). Melayu Proto datang ke Asia Tenggara kira-kira 2500 SM dan membawa kebudayaan Neolitik. Sedangkan melayu Deutro datang sekitar 300 SM dan membawa kebudayaan besi dan perunggu di wilayah Asia Tenggara.

Menurut teori Sarasin, keturunan Melayu Proto telah dipaksa pindah ke daerah pedalaman setelah kedatangan kelompok Melayu Deutro. Kelompok baru ini menetap di keseluruhan kepulauan Melayu dan lambat laun dapat mengawal kawasan pantai kepulauan Asia Tenggara. Keberhasilan kelompok Melayu Deutro mengawal kawasan pantai dikarenakan mereka memiliki semangat pengembaraan dan keahlian sebagai pelaut.

Perpindahan penduduk di Asia Tenggara merupakan satu fenomena yang berlaku sejak manusia tiba di wilayah ini. Perpindahan senantiasa berlaku antara Tanah Melayu dengan Sumatera, Sumatera dengan Jawa, Jawa dengan Tanah Melayu dan lain-lain karena berasal dari rumpun yang sama, maka perpindahan mereka dari satu negeri ke negeri lain di kawasan ini tidak dianggap sebagai perpindahan ke luar negeri tetapi sebagai perpindahan dari sebuah kampung ke kampung lain.

Masyarakat Melayu di Kepulauan Melayu adalah masyarakat pelaut (maritime societies). Sebagai masyarakat pelaut, mereka berlayar ke seluruh pelosok kawasan tersebut. Akibatnya bahasa mereka, yaitu bahasa Melayu telah menjadi lingua franca di kepulauan ini. Sebenarnya bahasa ini hanya ditutur oleh penduduk di beberapa bagian Sumatera dan Semenanjung Tanah Melayu. Bahasa Melayu mendapat dorongan luar biasa untuk berkembang sebagai lingua franca karena perkembangan perdagangan dan pelabuhan-pelabuhan di Semenanjung Tanah Melayu dan Sumatera. Pusat-pusat perdagangan ini telah menjadi tempat pertemuan bagi orang-orang dari seluruh wilyah Asia Tenggara. Penggunaan bahasa Melayu telah menyatukan hampir semua suku bangsa Indonesia (Vlekke, 1967:12).
Dari segi agama, terdapat persamaan antara Indonesia dan Malaysia. Dibanding dengan negara-negara lain di Asia Tenggara, Islam menjadi agama yang berpengaruh dan dominan dalam kehidupan masyarakat di kedua wilayah tersebut. Dari segi kepercayaan, Islam merupakan elemen yang membedakan penduduk Tanah Melayu dan Indonesia dengan penduduk Asia Tenggara yang lain. Hal ini disebabkan mayoritas penduduk Asia Tenggara daratan adalah penganut Budha dan Katolik di kepulauan Filipina.

Dari segi kebudayaan, tanah Melayu dan Indonesia menerima banyak unsur dari kebudayaan India, namun unsur kebudayaan India lebih banyak terlihat dalam kebudayaan Indonesia terutama dalam arsitektur dan seni ukir. Dalam mengkaji hubungan awal, terdapat persamaan dalam aspek kebudayaan antara kedua negara. Karena letak geografisnya di jalur perdagangan internasional antara lain jalur perdagangan antara India dan Cina, kedua wilayah ini Tanah Melayu dan Indonesia mendapat pengaruh cukup besar dari kebudayaan India dan Arab. Bahkan pada akhirnya banyak produk budaya kedua bangsa Indonesia dan Malaysia merupakan perpaduan antara nilai lokal dan unsur asing seperti pengaruh India, Cina dan Arab. Contohnya adalah wayang (cerita Mahabharata) dan seni tari Zapin (pengaruh Arab).

Perkembangan Islam telah membawa dampak yang penting dalam hubungan awal kedua negara. Islam telah menjadi salah satu faktor pemersatu kedua bangsa. Dibandingkan era Majapahit dan Sriwijaya, hubungan kedua bangsa terjalin semakin erat di masa Kesultanan Malaka pada abad ke-14, sebuah Kesultanan Islam yang memiliki peran penting dalam perdagangan dan penyebaran Islam di kepulauan Nusantara. Di samping itu terjadinya perkawinan antara anggota keluarga kerajaan, telah mengeratkan hubungan antara satu kerajaan dengan kerajaan lainnya.

Sebelum masuknya kolonialisme Inggris dan Belanda di Tanah Melayu dan Indonesia. Masyarakat kedua bangsa dihubungkan secara politis oleh kerajaan-kerajaan yang secara bergantian saling mempengaruhi satu dengan 
lainnya. Beberapa kerajaan besar pada masa lalu secara bergantian saling menguasai satu wilayah yang sama, contohnya kekuasaan kerajaan Aceh meliputi sebagian wilayah Semenanjung Malaysia, begitu pula dengan kerajaan Riau Lingga wilayah kekuasaanya sampai ke wilayah Johor.

Kerajaan atau kesultanan di Malaysia banyak yang berhubungan erat dengan kesultanan yang ada di Indonesia. Penduduk Tanah Melayu tidak melihat orang-orang Bugis dan Minangkabau sebagai orang asing. Ini terbukti apabila penduduk Selangor menerima Raja Lumu anak dari pembesar Bugis Daeng Chelak sebagai sultan mereka pada tahun 1742 (Trenggoning, 1994:60). dan penduduk Negeri Sembilan menerima Raja Melewar yang keturunan Minangkabau menjadi raja Negeri Sembilan (Yang Dipertuan Besar Negeri Sembilan) pada tahun 1773 (Tate, 1997:158 dan 268).

Kesultanan Selangor dan Johor memiliki hubungan yang erat dengan Sulawesi Selatan karena sultan Selangor dan Johor adalah keturunan Bugis (Trenggoning, 1994:62). Demikian juga Kesultanan Malaka didirikan oleh Parameswara seorang pangeran dari Sriwijaya (Palembang) yang melarikan dari serangan Majapahit ke Tumasik/Singapura.. Parameswara berhasil mendirikan Kesultanan Malaka sekitar tahun 1400 di Tanah Melayu yang nantinya berkembang sebagai kota dagang terbesar di jamannya menggantikan kerajaan Sriwijaya (Wolters, 1970:32).

Adapun, Kesultanan Perak sangat erat kaitannya dengan Aceh. Hal ini terjadi karena ketika Aceh menyerang Perak pada tahun 1575, Putera Sulung Sultan Perak diambil sebagai suami oleh Ratu Aceh. Empat tahun kemudian putera Sultan Perak tersebut menjadi Raja atau Sultan di Aceh (Andaya,1982:69, Trenggoning, 1994:52, dan Miller, 1965:52). Kemudian Sultan ini mengirim adiknya ke Perak yang kemudian bertahta sebagai Sultan Perak. Tindakan ini mempererat hubungan kekeluargaan antara Aceh dengan Perak.

Hubungan politik dan budaya yang sangat dekat ini kemudian berubah setelah kedatangan bangsa-bangsa Barat terutama Belanda dan
Inggris yang kemudian menguasai Tanah Melayu dan Indonesia. Perjanjian London 1824 yang di kenal sebagai Treaty of commerce and Exchange Between Great Britain and Netherlands, dapat dikatakan merupakan titik awal terpisahnya secara politik antara Tanah Melayu dan Indonesia.

Perjanjian ini membagi dunia Melayu menjadi dua kawasan yang berlainan dari segi politik. Berdasarkan Pasal 9 dan 10 perjanjian ini, pihak Inggris setuju menyerahkan semua pusat perdagangannya di Sumatera kepada pihak Belanda dan tidak akan membuat sembarang perjanjian dengan pemimpin lokal di pulau tersebut (Sar-Desai, 1981:58). Belanda juga menyerahkan kota Malaka dan kawasankawasannya di Semenanjung Tanah Melayu kepada pihak Inggris, dan tidak akan membuat perjanjian dengan pemimpin lokal di Semenanjung. Perjanjian ini juga menjadi dasar bagi negara Indonesia modern dan Malaysia. Penjajahan Inggris atas Tanah Melayu dan Penjajahan Belanda atas wilayah kepulauan Indonesia, selanjutnya memberi pengalaman sejarah yang berbeda bagi kedua bangsa.

\section{PERANG DINGIN DI ASIA TENGGARA}

Perang Dingin (Cold War) adalah sebutan bagi sebuah periode dimana terjadi konflik, ketegangan, dan kompetisi antara Amerika Serikat bersama sekutunya disebut Blok Barat dan Uni Soviet beserta sekutunya disebut Blok Timur yang terjadi antara tahun 1947-1991.

Istilah Perang Dingin diciptakan oleh ahli keuangan Amerika Serikat Bernard Baruch, pada April 1947. Istilah ini diciptakan untuk menggambarkan suatu keadaan hubungan antar negara yang berupaya untuk mengalahkan dan menjegal pihak lain yang termanifestasi di dalam tekanantekanan ekonomi, propaganda, kegiatan-kegiatan rahasia dan subversif, aksi politik di pertemuanpertemuan organisasi internasional, langkahlangkah yang senantiasa menghentikan segala macam pertempuran yang sebenarnya "perang panas" atau "perang tembakan". Istilah ini digunakan secara longgar untuk melukiskan se- 
luruh periode hubungan antara Uni Soviet dan Amerika Serikat setelah berakhirnya Perang Dunia II. Istilah ini digunakan Bernard Baruch tanggal 16 April 1947 sebulan setelah pengumuman Doktrin Truman.

Frasa ini kemudian digunakan oleh Walter Lippmann dalam ruangan surat kabar yang disindikatkan, dan dengan segera berubah menjadi bahasa metaphor yang secara tepat menggambarkan situasi yang muncul antara kekuatan Barat dengan Uni Soviet pada musim semi 1947 (Rees, 1968:66).

Berakhirnya Perang Dunia II melahirkan dua blok yang bertentangan secara ideologi. Blok Komunis yang dipelopori oleh Uni Soviet berhadapan dengan blok Kapitalisme yang dipimpin Amerika Serikat. Amerika dan Uni Soviet sebagai pemenang Perang Dunia II memiliki paham ideologi yang berbeda. Amerika Serikat memiliki ideologi liberal-kapitalis, sedangkan Uni Soviet berideologi komunis. Paham Liberal-Kapitalis (AS) yang mengagungkan kebebasan individu yang memungkinkan kapitalisme berkembang dengan subur bertentangan dengan paham sosialis -komunis (US) yang beranggapan bahwa paham itu dapat lebih mempercepat kesejahteraan buruh maupun rakyatnya karena negara yang mengendalikan perusahaan akan memanfaatkan untuk kesejahteraan rakyat.

Perang Dingin dimulai setelah berakhirnya Perang Dunia II sejak pembagian Jerman menjadi dua, diikuti dengan pembagian kota Berlin menjadi Berlin Barat yang dikuasai oleh Amerika Serikat, Inggris, dan Perancis. Sedangkan Berlin Timur dikuasai oleh Uni Soviet. Dalam waktu singkat (1945-1948) Uni Soviet berhasil membentuk pemerintah komunis di Bulgaria, Rumania, Honggaria, Polandia dan Chekoslowakia. Karena perkembangan pengaruh Uni Soviet yang sangat cepat, Amerika Serikat merasa perlu membendung perkembangan gerakan komunis. Hingga akhirnya Amerika Serikat menyusun strategi politik Containment Policy yang bertujuan mencegah berkembangnya pengaruh suatu negara atau suatu sistem politik pihak lawan. Strategi politik ter- sebut dikembangkan melalui pemberian bantuan ekonomi dan militer seperti Marshall dan Doktrin Truman yaitu bantuan berupa keuangan, militer, dan penasehat militer kepada Yunani Turki guna menghadapi gerilyawan komunis dan menghambat jalur Uni Soviet menuju ke selatan yang akan mengancam negara-negara Barat. Sebab jika salah satu negara jatuh maka negara tetangga lainnya akan jatuh ke dalam pengaruh komunis. Uni Soviet berusaha menyaingi dengan membuat Molotov Plan dengan tujuan menata kembali perekonomian negara-negara Eropa Timur dan badan kerja sama ekonomi Comicon (Comintern Economic). Konflik ideologi tersebut berkembang sampai Asia.

Kekalahan Jepang terhadap Sekutu yang menyebabkan seluruh wilayah Manchuria dan Korea diduduki oleh Uni Soviet. Hal ini berdampak semakin kuatnya Uni Soviet di daratan Cina serta wilayah Korea. Berdasarkan konferensi Yalta Semenanjung Korea dibagi dua yaitu Utara dibawah kekuasaan Uni Soviet, sedangkan wilayah Selatan dibawah kekuasaan Amerika Serikat. Karena adanya perbedaan ideologi ini mengakibatkan perang saudara di semenanjung Korea pada 25 Juni 1950.

Perkembangan komunisme di Asia diawali dengan kemenangan kelompok komunis Cina di bawah pimpinan Mao Tze Tung terhadap Kuomintang yang disusul dengan pembentukan negara Republik Rakyat Cina (RRC) pada tanggal 1 Oktober 1949. RRC menjadi negara komunis terbesar di Asia dan kedua terbesar di dunia setelah Uni Soviet. Cina berusaha menyebarkan pengaruhnya di Asia terkait keinginan mengembalikan daerah kekuasaan Cina di zaman kuno meliputi Korea, Funan, Burma, India, bahkan lebih jauh termasuk daerah Asia Tenggara. Selain alasan historis juga adanya alasan geografis dan kekayaan alam di Asia Tenggara guna memperkuat posisi ekonominya di wilayah ini. Hal ini menjadi masalah yang cukup serius bagi Amerika Serikat sehingga membuat Amerika Serikat merasa perlu membantu negara-negara Asia Tenggara.

Amerika Serikat kemudian memutuskan membantu Perancis yang pada saat itu berperang 
dengan kekuatan nasionalis Vietnam dibawah pimpinan Ho Chi Minh yang dibantu oleh Uni Soviet dan Cina, dengan harapan Vietnam tidak jatuh ketangan komunis. Namun kejatuhan Vietnam ketangan komunis akhirnya terjadi dengan kekalahan Perancis pada pertempuran di benteng Dien Bien Phu tahun 1954. Jatuhnya Vietnam ke dalam kekuasaan komunis dikhawatirkan akan membawa efek domino terhadap negara-negara lainnya di Asia Tenggara. Perjanjian Jenewa yang diharapkan bisa menyelesaikan konflik Vietnam, dengan membagi Vietnam menjadi dua (Utara: Komunis, Selatan: Liberal-Kapitalis), justru menjadikan Vietnam sebagai arena baru persaingan ideologi di Asia Tenggara pada masa Perang Dingin.

Kemenangan komunis Vietnam atas Perancis pada tahun 1954 memberikan dampak langsung bagi rancangan politik dan keamanan Amerika Serikat atas Asia Tenggara. Jatuhnya sebagian Vietnam ketangan kelompok komunis mendorong Amerika Serikat membentuk Pakta Pertahanan Militer Asia Tenggara (SEATO) pada 8 September 1954. Tujuan utama pembentukan SEATO adalah menjaga dan mencegah negara-negara demokratis di Asia Tenggara menjadi negara komunis.

Kawasan Asia Tenggara sangat penting bagi politik ekonomi dan keamanan Amerika Serikat. Secara garis besar ada dua kepentingan Amerika Serikat di Asia Tenggara berkaitan letaknya yang strategis; Asia Tenggara membuka garis laut, karena sebagian besar perdagangan dunia melewati selat Malaka; Asia Tenggara sangat penting sebagai pos untuk pergerakan kehadiran militer Amerika Serikat di pasifik Barat dan Samudera Hindia. Asia Tenggara secara geopolitik sangat krusial tidak hanya untuk kepentingan nasional Amerika Serikat, tetapi juga secara global. Jalur laut yang melintasi kawasan Asia Tenggara mempunyai fungsi yang vital bagi ekonomi Jepang, Republik Korea Selatan, Cina dan termasuk Amerika Serikat sendiri

Pada saat perang Dingin berkecamuk di Asia Tenggara, beberapa negara Asia Tenggara yang baru saja memperoleh kemerdekaan, secara tidak langsung ikut terseret kedalam persaingan kedua ideologi tersebut. Filipina dan Thailand karena alasan keamanan nasional dan ketergantungan ekonomi nya dengan Barat sikapnya condong ke Blok Barat. Bahkan dua negara ini ikut bergabung ke dalam Pakta Pertahanan SEATO. Sama halnya dengan Malaysia, karena keamanan nasionalnya oleh pemberontakan Partai Komunis Malaya yang di dukung Cina, seta kertergantungan ekonominya dengan Inggris, memiliki kebijakan luar negeri yang pro Barat dan anti komunis. Malaysia bersama Inggris, menandatangani Pakta pertahanan bersama yang dikenal dengan AMDA (Anglo Malayan Defence Agreement).

Namun, di pihak lain ada beberapa negara di Asia Tenggara yang berusaha bersikap netral dan tidak memihak terhadap konflik ideologi yang terjadi saat itu, seperti Indonesia, Myanmar, Laos dan Kamboja. Pengalaman perjuangan Indonesia mendapatkan pengakuan kedaulatan nya melalui revolusi fisik yang berlangsung selama lima tahun, telah membentuk sikap nasionalisme yang mirip dengan Vietnam. Di Asia Tenggara hanya dua negara yang pernah mengalami perjuangan revolusi bersenjata terhadap mantan penjajahnya yaitu Vietnam dan Indonesia. Namun berbeda dengan Vietnam yang memilih kebijakan luar negeri yang prokomunis, Indonesia sampai awal tahun 1960 an berusaha bersikap netral dan tidak memihak.

\section{SITUASI POLITIK DOMESTIK INDONE- SIA-MALAYSIA}

Setelah mendapatkan pengakuan kedaulatannya pada bulan Desember 1949, dari periode 1950-1959, Indonesia memilih sistem politik Demokrasi Liberal ala Barat. Di mana kekuasaan tertinggi pemerintahan ada di tangan seorang Perdana Menteri, sedangkan Presiden hanya di anggap sebagai kepala negara. Sistem demokrasi liberal ini sebenarnya sudah dijalankan oleh Republik Indonesia sejak awal tahun 1946, ketika Sutan Syahrir ditunjuk sebagai Perdana Menteri pertama Republik Indonesia. Pilihan untuk memilih sistem ini didasari oleh taktik perjuangan diplomasi Indonesia saat itu. Pada 
awalnya Belanda tidak mau melakukan negosiasi sama sekali dengan Republik Indonesia, karena dinilai sebagai negara bentukan Jepang yang otoriter. Sebagai taktik diplomasi, Soekarno kemudian mengubah sistem pemerintahan presidensil menjadi sistem parlementer, dan mengijinkan terbentuknya partai-partai politik. Karena sistem parlementer adalah sistem politik yang dianut oleh negara-negara Eropa, saat itu Indonesia sedang berusaha mencari dukungan internasional atas kemerdekaannya, jadi hal tersebut di nilai sebagai pilihan yang tepat.

Munculnya pemberontakan daerah, jatuh bangunnya kabinet ditambah kegagalan Dewan Konstituante (hasil pemilu 1955) membentuk konstitusi baru, telah melemahkan sistem Parlementer di Indonesia. Akibatnya pada 1959 Soekarno mengeluarkan dekrit presiden yang mengembalikan kembali sistem pemerintahan sesuai dengan UUD 1945 yang disebutnya sebagai Demokrasi Terpimpin. Pemerintahan Demokrasi Terpimpin dimulai sejak dikeluarkannya Dekrit Presiden 5 Juli 1959.

Perkembangan politik masa Demokrasi Terpimpin terpusat pada Presiden Soekarno dengan TNI AD dan PKI sebagai pendukung utamanya. Ajaran Presiden Soekarno tentang Nasakom (Nasionalis, Agama, Komunis) sangat menguntungkan PKI karena menempatkannya sebagai bagian yang sah dalam konstelasi politik Indonesia. Pada Masa Demokrasi Terpimpin, parlemen sudah tidak mempunyai kekuatan yang nyata. Sementara itu partai-partai lainnya dihimpun oleh Soekarno dengan menggunakan suatu ikatan kerjasama yang di dominasi oleh sebuah ideologi

Kebijakan Luar Negeri selama Demokrasi Terpimpin menjadi kewenangan pribadi Soekarno dengan dukungan militer dan PKI sebagai bagian dari aktor utama politik Indonesia. Kedua kekuatan politik itu selanjutnya saling bersaing untuk mendapat simpati Soekarno, selama tahun-tahun pertama Demokrasi Terpimpin suatu perimbangan kekuatan terjadi antara Soekarno, Angkatan darat dan PKI.

Politik luar negeri Indonesia pada era ini, diabadikan pada tujuan nasional Indonesia. Pada saat itu kepentingan nasional Indonesia adalah pengakuan kedaulatan politik dan pembentukan identitas bangsa. Kepentingan nasional itu diterjemahkan dalam suatu kebijakan luar negeri yang bertujuan untuk mencari dukungan dan pengakuan terhadap kedaulatan Indonesia, dan untuk menunjukan karakter yang dimiliki pada bangsa-bangsa lain di dunia internasional.

Landasan Diplomasi pada periode Demokrasi terpimpin berdasarkan UUD 1945, yang terdapat dalam pembukaan UUD 1945 alinea pertama dan batang tubuh UUD 1945 yaitu pasal 11 dan pasal 13 ayat 1 dan 2 Amanat Presiden yang berjudul "Penemuan Kembali Revolusi Kita" pada 17 Agustus 1959 atau dikenal sebagai "Manifesto Politik Republik Indonesia" telah dijadikan sebagai Garis Besar Haluan Negara di bidang politik luar negeri. Di dalam Manifesto Politik tersebut terdapat tujuan jangka pendek dan jangka panjang yaitu;

Tudjuan djangka pendek jaitu melandjutkan perdjuangan anti imperialisme ditambah dengan mempertahankan kepribadian Indonesia di tengah-tengah tarikan-tarikan ke kanan dank e kiri jang sekarang sedang berlaku kepada negara kita dalam pergolakan dunia menudju kepada suatu imbangan baru. Semenatra dalam djangka pandjang di bidang luar negeri, Revolusi Indonesia bertudjuan melenjapkan imperialisme di mana-mana, dan mentjapai dasar-dasar bagi perdamaian dunia jang kekal dan abadi. Menurut Manipol, diplomasi jang sesuai dengan fungsinja sebagai art jang berhubungan dengan tjara melaksanakannja harus tidak mengenal kompromi, harus radikal dan revolusioner (Panitya Penulisan Sedjarah Luar Negeri, 1972:259).

Tujuan jangka pendek dan jangka panjang tidak terlepas dari sejarah Indonesia, sebagai bangsa yang pernah mengalami penjajahan. Walaupun Indonesia sudah merdeka, perjuangan untuk melenyapkan imperialisme belum berakhir, sebab negara-negara yang dianggap imperialis dan kolonialis (Barat), masih ada dan berusaha menanamkan pengaruhnya. Indonesia 
berusaha pula menghindari dari keberpihakan dua blok yang bersengketa dan masuk menjadi anggota Non Blok

Pedoman Pelaksanaan Manifesto Politik Indonesia berdasarkan pada amanat Presiden tanggal 17 Agustus 1960 yang terkenal dengan nama "Djalanja Revolusi Kita", yang menetapkan penegasan mengenai cara-cara pelaksanaan Manipol di bidang politik luar negeri. Politik luar negeri Indonesia tidak netral, tidak menjadi penonton dan tidak tanpa prinsip. Politik bebas tidak sekedar "cuci tangan", tidak sekedar defensif, tapi aktif dan berprinsip serta berpendirian (Panitya Penulisan Sedjarah Luar Negeri, 1972:259). Manipol, Djarek (Djalanja Revolusi Kita), merupakan embrio kelahiran serta doktrin baru, yaitu dunia tidak terbagi dalam blok Barat dan blok Timur, tidak juga dalam tiga blok dimana Asia Afrika merupakan blok ketga. Akan tetapi dunia terbagi menjadi dua blok yaitu New Emerging Forces /Nefos dan Old Established Forces/Oldefos

Nefos merupakan kekuatan-kekuatan baru yang sedang bangkit. Sementara Oldefos merupakan kekuatan-kekuatan lama yang sudah mapan. Doktrin Nefos dan Oldefos menjadi dasar politik luar negeri anti imperialis dan kolonialis yang lebih militan. Soekarno mewujudkan gagasan Nefos dan Oldefos itu dengan suatu strategi diplomasi yang agresif dan konfrontatif dengan negara-negara Barat.

Dalam kondisi sistem politik seperti inilah, Federasi Malaysia diproklamirkan, Soekarno menilai federasi Malaysia adalah usaha dari negara-negara lama/Oldefos yang tetap ingin menancapkan kekuasaan dan pengaruhnya di Asia Tenggara.

Sementara itu situasi politik yang berkembang berbeda dengan situasi yang terjadi di Indonesia. Sebelum pembentukan Federasi Malaysia 1963, Tanah Melayu telah memperoleh kemerdekan dari Inggris sejak tahun 1957, dengan bentuk Monarki Konstitusional yang menganut sistem Demokrasi Parlementer. Sebagai kepala negara adalah Yang Dipertuan Agung, Raja Malaysia yang dipilih secara bergilir dari beberapa kesultanan yang bergabung yang masih berdiri. Dari 13 Negara bagian, hanya Serawak, Sabah dan Pulau Pinang yang tidak memiliki kesultanan. Perdana Menteri sebagai kepala pemerintahan di pilih oleh rakyat melalui Pemilu yang berlangsung selama 5 tahun sekali. Malaysia menganut sistem politik multi partai dengan partai terbesar $\mathrm{UMNO} /$ United Malay National Organization yang sejak Malaysia memperoleh kemerdekaan selalu menjadi pemegang kendali pemerintahan. Elitelit politik melayu sebagian besar berasal dari partai ini. Selanjutnya ada beberapa partai lainnya seperti Partai Islam SaMalaya (PAS), Malayan Chinese Association), Malayan Indian Congres /MIC dan partai partai lokal yang ada di Sabah dan Serawak. Ciri penting perpolitikan di Malaysia adalah komunalisme, pembentukan partai politik didasarkan etnis atau ras yang ada, seperti MCA adalah partai orang-orang Cina, MIC partainya orang India, PAS dan UMNO adalah partainya orang Melayu.

Sejak awal kemerdekaannya, UMNO bersama dengan MCA dan MIC bergabung dalam satu koalisi politik yang bernama Barisan Nasional/BN. Koalisi inilah yang memegang kendali pemerintahan Malaysia sejak merdeka. Perdana Menteri pertama Malaysia adalah Tunku Abdul Rahman. Sejak tahun 1957 sampai akhir 1960an, Tunku mendominasi kebijakan luar negeri Malaysia. Politik luar negeri Malaya/Malaysia sampai akhir 1960-an dapat dikatakan sebagai era Tunku. Karena pada masanya kebijakan luar negeri Malaysia merupakan kebijakan dari Tunku. Hampir semua keputusan penting dibuat Tunku sendiri tanpa membicarakannya terlebih dahulu dengan pemimpin-pemimpin lainnya. Sebagai contohnya pada masa isu pemisahan di antara Malaysia dan Singapura, Tunku hanya membicarakan hal tersebut secara informal dengan Tun Abdul Razak dan Tun Ismail dan tidak membawa masalah ini dalam sidang kabinet (Ahmad, 1987:1).

Di bawah pimpinan Tunku Abdul Rahman sebagai Perdana Menteri pertama, Malaysia lebih memfokuskan hubungan luar negerinya dengan negara-negara Barat yang mempunyai 
sistem pemerintahan dan ideologi yang sealiran dengannya. Tunku pernah menyatakan prinsip kebijakan luar negeri yang dijalankannya adalah "Tanah Melayu bukanlah sebuah negara berkecuali. Kita anti komunis dan menyokong pihak Barat" (Wahid dan Abidin, 1978:15).

Mengenai bagaimana politik luar negeri Malaya pada saat itu diformulasikan dan dijalankan, Marvin Ott dalam kajiannya menyimpulkan bahwa pada intinya kebijakan luar negeri Malaysia saat itu diformulasikan oleh sekelompok kecil elit yang terdiri dari empat atau lima orang dan Tunku sebagai Perdana Menteri yang juga merangkap Menteri Luar Negeri memiliki peranan yang paling menentukan (Marvin, 1972:257).

Faktor lain yang juga turut menetukan arah politik luar negeri Malaysia saat itu adalah faktor ekonomi. Sejak Malaya/Malaysia mereka pada 1957 hingga 1960-an, hampir 70\% dari perdagangan luar negeri dikuasai oleh perusahaan Eropa terutama perusahaan-perusahaan Inggris. Malaysia merupakan penghasil karet terbesar dunia dan $83 \%$ perkebunan karet dimiliki perusahaan Eropa. Malaysia juga penghasil timah terbesar dunia dan $63 \%$ bijih timah yang dihasilkan dan diolah oleh perusahaan asing. Sehingga dari data diatas terlihat bahwa ekonomi Malaysia masih sangat tergantung dengan negara-negara Barat.

Dari aspek militer, situasi keamanan dalam negeri dirongrong oleh pemberontakan komunis yang telah berlangsung sejak tahun 1948. Para pemimpin Malaysia dan rakyat Malaysia pada umumnya percaya bahwa sumber pemberontakan komunis itu datangnya dari Beijing, sebab pelaku utama pemberontakan dan anggota Partai Komunis Malaya (PKM) mayoritas adalah etnis Cina dan diatur dari Cina. Karena itu, pemerintah Malaya/Malaysia selalu memandang RRC sebagai ancaman utama bagi keamanan nasionalnya. Para pemimpin Malaysia terutama Tunku sangat yakin bahwa Cina sedang berusaha untuk membentuk satu rangkaian "kediktatoran komunis di Asia Tenggara“(Marvin, 1972:257).
Dalam situasi politik domestik dan kepentingan nasional yang berbeda inilah "Rancangan Pembentukan Federasi Malaysia " di cetuskan. Kedua pihak tidak menemukan titik temu untuk menyelesaikan perbedaan pendapat yang terjadi diantara mereka, akibatnya muncul konflik yang berujung pada pecahnya peristiwa konfrontasi. Soekarno sebagai seorang yang dikenal kritis terhadap Barat berhadapan dengan Tunku Abdul Rahman "bangsawan Melayu “ yang feodal dan "Pro Barat". Perbedaan pandangan dan kepribadian kedua tokoh ini menambah panas situasi hubungan kedua negara saat itu.

\section{PENUTUP}

Dari uraian pembahasan di atas, dapat tergambar bahwa kedudukan geografis dan geopolitik Asia Tenggara memiliki dampak yang sangat besar terhadap perubahan-perubahan budaya, sosial dan politik wilayah Asia Tenggara secara keseluruhan. Indonesia dan Malaysia sebagai dua negara yang memiliki letak geografis yang paling strategis dan berbatasan secara langsung melalui laut dan darat, mendapatkan banyak pengaruh dari luar yang kemudian membentuk banyak persamaan dari segi sejarah dan budaya. Namun pengalaman kolonialisme yang berbeda, berdampak pada pembentukan karakter dan persepsi yang berbeda terhadap masalah keamanan nasional masing-masing negara. Hal ini tercermin dari bentuk kebijakan luar negeri yang berbeda sejak kedua negara memperoleh kemerdekaan dengan cara yang berbeda pula, Indonesia melalui revolusi, Malaysia melalui proses transisi damai.

Karena posisi geografis yang strategis ini pulalah, yang kemudian juga menjadikan Asia Tenggara sebagai arena perebutan pengaruh ideologi antara blok Barat dan blok Timur pada masa perang dingin. Dalam menghadapi situasi perang dingin yang terjadi, Indonesia dan Malaysia, berlatar belakang kepentingan nasional yang berbeda, berada dalam dua kubu yang bersebrangan. Dalam Persfektif Regional peristiwa konfrontasi merupakan bagian dari interkoneksi 
antara situasi politik global- regional dan domestik kedua negara.

\section{DAFTAR RUJUKAN}

Ahmad., A.1987. Tunku Abdul Rahman dan Dasar Luar Malaysia 1963-1970. Kuala Lumpur: Berita Publishing Sdn Bhd

Bunnel, F. P. 1966. "Guided Democracy Foreign Policy 1960-1965 : Presiden Soekarno Moves from Non Alignment to Confrontation", dalam Indonesia, October 1966. Ithaca, NY : Modern Indonesia Project Cornell University.

Hall, DGE. 1988. Sejarah Asia Tenggara. Surabaya: Usaha Nasional

Hardjono, J. 1971. Indonesia Land and People. Jakarta : Gunung Agung,

Harrison, B. 1966. Asia Tenggara : Suatu Sejarah Ringkas, Kuala Lumpur: Dewan Bahasa Pustaka.

Leifer, M. 2005. Selected Works on Southeast Asia. Singapore : Institute of Southeast Asian Studies

Ott, M. "Foreign Policy Formulation in Malaysia". Asean Survey, vol.12, no.3 (Mar.,1972). University California Press,

Panitya Penulisan Sedjarah Departemen Luar Negeri, 1971 .25 Tahun Departemen Luar Negeri. Jakarta: Yayasan Kesejahteraan Departemen Luar Negeri

Rees, D. 1968. The Age of Containment, The Cold War.

Sar Desai, D.R. 1981. Southeast Asia: Past and Present. New Delhi : Vikas Publishing House

Sokolosky, R dkk. 2000. "The Role of Southeast Asia in US Strategy Toward China", Santa Monica: Rand,

Sunarti, L. 2013. Persaudaraan Sepanjang Hayat: Mencari Jalan Penyelesaian Damai Konfrontasi
Indonesia-Malaysia. Jakarta : Serat Alam Media

Tate, D.J.M. 1977. The Making of Modern Southeast Asia. Kuala Lumpur: Oxford University Press;

Vlekke, B.H.M. 1967. Nusantara: Sejarah Indonesia. Kuala Lumpur: Dewan Bahasa dan Pustaka

Wahid, A dan Zainal Abidin. 1978. Sejarah Dasar Luar Malaysia. Kuala Lumpur: Kementrian Belia dan Sukan

Warshaw, S.1975. Southeast Asia Emerges: A Concise History of Southeast Asia From its Origin to the Present. Berkeley California : Diablo Press

Weinstein, F B. 1976. Indonesia Foreign Policy and the Dillema of Independence from Soekarno to Soeharto. Ithaca NY : Cornell University Press 